18-month annealing stage, and is being ground and polished, the grinding "head" being a 12-tonne ribbed aluminium disk bearing plexiglass plates. The temperature regime of the grinding and checking process is controlled by a special conditioning system, and temperature deviations in the grinding shop are not allowed to exceed one-tenth of a degree centigrade. During the checking of the mirror surface only two persons can be present in the grinding shop; it is considered that the respiration of a third person would be sufficient to disturb the thermal regime of the mirror unit and vitiate the measurements. The Pravda article gives no clear indications as to when the mirror is likely to be finished.

\section{Glaxo Science Writer}

THE fifth annual Glaxo award for science writing in British journals and newspapers has been awarded to Nicholas Wade, assistant editor of Nature. The award, which consists of a travelling fellowship worth $£ 500$, will be presented on July 16 by Sir Alan Wilson, chairman of the Glaxo group. Previous awards in this series have been made to $\mathrm{Mr}$ Graham Chedd (New Scientist), $\mathrm{Mr}$ John Davey (Observer) and $\mathrm{Mr}$ Peter Fairley (Evening Standard). Apart from contributions to Nature, $\mathrm{Mr}$ Wade has been for close on two years news editor of the NatureTimes News Service and has contributed to several other journals and to $\mathrm{BBC}$ radio. $\mathrm{He}$ has been appointed deputy editor of Nature from the beginning of this week and will be Washington correspondent of Nature from mid-July.

The committee responsible for the Glaxo award, which represents the Association of British Science Writers and the National Council for the Training of Journalists, also announced last week an award of $£ 500$ to Mr Joseph McKiernan of the Newcastle Evening Chronicle for his work in regional newspapers. Mr McKiernan has been a journalist for 25 years, four of which were spent as a district reporter in Africa.

\section{EPIDEMICS}

\section{Containing the Plague}

THe plague epidemic which invaded the world in the nineteenth century in the holds of the steam ship may break out once more in the wake of container ships. This, at least, is the fear expressed in a report by the WHO Expert Committee on Plague (World Health Organization Tech. Rep. Ser. No. 447, 1970; 4s)

Few people now die of plague because the isolated outbreaks that occur are checked by antibiotics and sulphonamides and the chain between rat, flea and man is broken by pesticides. But natural reservoirs of the disease still exist and the WHO fears that freighting in containers, a rapidly growing form of transport, may help to spread Pasteurella pestis since cargo packed in infected areas and not inspected en route or on arrival could contain plague infected rats and fleas. There is also the fear that present methods of combating plague may lose their effectiveness as resistance mounts up.
To combat any resurgence of the plague the WHO committee recommends tighter methods of control and surveillance.

Countries with plague reservoirs-these include the United States, South Africa, the Soviet U'nion and parts of South America - as well as other nations should carry out regular serological and bacteriological surveys and a sharp watch should be kept for any signs of resistance to preventive methods in current use. The WHO committee also advises that an international reference centre should be set up to provide facilities for the free international exchange of plague strains.

\section{PARKS}

\section{Erosion Threat to Peak District}

The Peak District National Park Planning Board, which was awarded a Council of Europe diploma in 1966 for its work on landscape conservation, believes that without adequate funds the park's landscape may suffer an irreversible deterioration in quality. Some areas, such as the Goyt Valley and Dovedale, are being steadily eroded, according to the board's latest annual report, because planning and work cannot keep pace with the increasing pressures from people and motor cars. Money will be needed in the near future, in the Goyt Valley, for example, where after the completion in 1972 of the two-year traffic management experiment being promoted by the Countryside Commission (see Nature, 225, 577: 1970), some permanent solution to the area's problems - not necessarily the same as the experimental scheme-will have to be found and implemented.

Like other national park boards, the Peak District National Park Planning Board is hampered because it receives government grants of 75 per cent only for certain specific national park jobs, and not for its day to day running expenses which draw much more heavily on its resources. The board's plight is shown well by its 1969/70 accounts; against an expenditure of only $£ 74,000$ on what the board describes as "positive action" work which is eligible for government assist. ance-publicity and information work, tree planting and preservation, forestry, provision of accommodation, camping sites and car parks, and the warden service - the sum of $£ 101,000$ was spent on administration, 25 per cent more than the total available for specific projects.

\section{INFORMATION}

\section{Punching-up Rocks}

THE latest step in the moves to establish a national data bank at the Institute of Geological Sciences is the publication of a scheme for coding rock and mineral names into a format suitable for computers ( $A$ Petrological-Mineralogical Code for Computer Use, HMSO, £1). Devised in the first instance for application at the Institute of Geological Sciences, where automatic data-handling methods are being introduced, the code occupies four columns of the standard eightycolumn punched card. For example, if the only information about a specimen is that it is igneous, then it is coded as 1000, and a basic igneous rock becomes $1 \mathrm{E} 00$, a dolerite $1 \mathrm{~EB} 0$, and an olivine-dolerite 1EBB. The first digit represents one of nine divisions : undiffer- 